\begin{tabular}{|l|c|c|c|c|}
\hline $\begin{array}{l}\text { Cuadernos de Investigación Geográfica } \\
\text { Geographical Research Letters }\end{array}$ & 2020 & N $^{\circ} 46(1)$ & pp. 159-185 & eISSN 1697-9540 \\
\hline
\end{tabular}

\title{
RECENT EVOLUTION OF THE ACTIVE LAYER IN THE MORENAS COLORADAS ROCK GLACIER, CENTRAL ANDES, MENDOZA, ARGENTINA AND ITS RELATION WITH KINEMATICS
}

\author{
D. TROMBOTTO-LIAUDAT*, E. BOTTEGAL
}

\begin{abstract}
Geocryology, IANIGLA (Instituto Argentino de Nivología, Glaciología y Ciencias Ambientales), CCT Conicet Mendoza, Argentina.
\end{abstract}

\begin{abstract}
Between 2008 and 2016 the Morenas Coloradas rock glacier in the Central Andes of Mendoza showed different thermal characteristics at three monitoring sites in active layers, Balcón I (3560 m a.s.l.), Balcón I Superior (3590 $m$ a.s.l.) and Balcón II (3770 m a.s.l.). These can be explained by various factors, not only external ones related to the climatic variability and altitude, but also by thermal-hydrological factors that destabilized its internal cryogenic structure. At Balcón I, situated on a sloping terrace of the rock glacier, a transient layer even showed definitive signs of permafrost degradation in the recent years, transforming it in a thermal talik. Long-term studies of surficial boreholes showed that the $0^{\circ} \mathrm{C}$ isotherm is higher in altitude than the active front of the rock glacier and it has risen $40 \mathrm{~m}$ in altitude since the 1990s. As consequence of the thermal changes of the active layer, the rock glacier shows abrupt movements, particularly in its terminal part. Thus geodesic measurements to obtain different speeds and directions were made. At the monitoring area of Balcón I Superior, which lies on a superimposed lobe, the geodesic measurement points revealed significant kinematic activity in the period May 2015 - February 2016, when the largest displacement was approximately $2 \mathrm{~m}$ to the South, developing an advance of the front over Balcón I. At Balcón II however, the points moved much less, in the order of $0.30 \mathrm{~m} \mathrm{yr}^{-1}$. The present studies suggest that the largest cryogenic sedimentary movements are superficial, that is to say, they are located in the active layer and the supra-permafrost and are due to internal movements produced by melting water coming from the top of the cryoform, and from both sides of the upper basin of the valley.
\end{abstract}

Evolución reciente de la capa activa del glaciar rocoso Morenas Coloradas, Andes Centrales de Mendoza, Argentina, y su relación cinemática

RESUMEN. En el período 2008-2016 el glaciar de escombros de Morenas Coloradas, en los Andes Centrales de Mendoza, presentó en sus sitios de moni- 
toreo Balcón I (3560 m s.n.m.), Balcón I Superior (3590 m s.n.m.) and Balcón II (3770 m s.n.m.) situaciones térmicas de capa activa disímiles entre sí adjudicadas a varios factores, no solamente externos, relacionados con la variabilidad climática y la altura, sino con situaciones termo-hídricas desestabilizadoras de su estructura interna. En el sitio de monitoreo Balcón I, situado en una terraza inclinada y deprimida del glaciar de escombros, una capa transitoria mostró incluso signos definitivos de degradación del permafrost en los últimos años, transformando el sitio en un talik térmico. Estudios más prolongados con perforaciones superficiales demostraron que la isoterma de $0{ }^{\circ} \mathrm{C}$ se halla más alta que el frente activo del glaciar de escombros y que la misma había ascendido aproximadamente unos $40 \mathrm{~m}$ en altitud desde la década de 1990. Como consecuencia de los cambios térmicos en los perfiles de capas activas, el glaciar de escombros muestra movimientos rápidos, particularmente en su parte terminal. Por este motivo, se hicieron mediciones geodésicas para obtener las diferentes velocidades criodinámicas y sus direcciones. En el área de monitoreo de Balcón I Superior, que se encuentra en un lóbulo superpuesto a Balcón I, los puntos de medición geodésicos revelaron una actividad cinemática significativa en el período de mayo de 2015 a febrero de 2016, siendo el mayor desplazamiento de aproximadamente $2 \mathrm{~m}$ hacia el sur, desarrollando un avance del frente hacia Balcón I, Sin embargo, en Balcón II, los puntos geodésicos se movieron mucho menos, del orden de 0,30 $\mathrm{m}$ año ${ }^{-1}$. Los estudios actuales sugieren que los movimientos sedimentarios criogénicos más grandes son superficiales, es decir, se ubican en la capa activa, de transición y en el supra-permafrost y se deben a movimientos internos producidos por el derretimiento del agua proveniente de la parte superior de la crioforma, y de ambos lados de la cuenca alta del valle.

Key words: Rock glacier, permafrost, active layer, kinematics, climatic variability.

Palabras Claves: glaciar rocoso, glaciar de escombros, permafrost, capa activa, cinemática, variabilidad climática.

Received: 8 January 2019

Accepted: 15 May 2019

*Corresponding author: Darío Trombotto Liaudat, Geocryology, IANIGLA (Instituto Argentino de Nivología, Glaciología y Ciencias Ambientales), CCT Conicet, Av. Ruiz Leal s/n, Parque Gral. San Martín. CP: 5500. CC: 330, Mendoza, Argentina. E-mail address: dtrombot@lab.cricyt.edu.ar 


\section{Introduction}

A rock glacier (Catalano, 1926; Wahrhaftig and Cox, 1959; Corte, 1976a; Giardino et al., 1987; Barsch, 1996; Corte 1997) is a mass of rock fragments and finer material, on a slope, that -when active or inactive- contains ground ice (interstitial, massive, glacial or injection ice, see Trombotto Liaudat et al., 2014) and shows evidence of past or present movement. Rock glaciers indicate the presence of "mountain permafrost" (Andean permafrost) or permanently frozen ground (van Everdingen, 1998, Trombotto and Ahumada, 2005, Trombotto Liaudat et al., 2014).

The percentage of ground ice in a rock glacier may show a great variation in the vertical direction of the profiles, or in the horizontal extension of the geoform (Barsch, 1977; Haeberli et al., 1988). This would imply an irregular volumetric ice content that differentially affects the rheology of the geoform. It is a cryogenic landform, supersaturated with ice that, if active, moves downslope by the influence of gravity, which produces creep and deformation of the mountain ice-rich permafrost (Barsch, 1996; Trombotto Liaudat et al., 2014). These characteristic cryoforms of the Andean Cordillera are of key interest today because they are regarded as reservoirs of water in solid state Corte (1976a, 1976b), Buk, 1983, Trombotto et al., 1999, Ahumada et al., 2015. The Central Andes display a high concentration of rock glaciers, as pointed out by Corte (1976b).

The cryogenic conditions that affect a rock glacier are related with the thermal state of the soil (at or below freezing point) that affects a certain thickness, but as it is found in a mountain area it is also affected by other dynamic processes as the soil moves slope downwards due to gravity and plastic deformation (Corte and Trombotto, 1984). That is why it is also called creeping permafrost (Haeberli, 1985).

The upper sedimentary layer that covers the permafrost of the rock glaciers is called the "active layer" (van Everdingen, 1998; Trombotto Liaudat et al., 2014). It is the upper layer of cryogenic soil that is subject to the annual freezing-thawing cycles. It thaws in summer, and this is when it reveals very important physico-chemical processes. It is the receptor that reflects seasonal changes. The active layer usually thins with increasing altitude.

As a consequence of climatic variability, the rise of the mean temperature in the study area during the 20th century (Rosenblüth et al., 1997) also affects the Andean periglacial environment and therefore rock glaciers. They move faster, modify their surface, enriching it in collapse structures or thermokarst, and can show parts or lobes without any sign of activity.

Because rock glaciers are sensitive to climatic and hydrologic factors, they are indicators of environmental changes. For this reason, the active layer of the rock glacier Morenas Coloradas has been monitored since 1989 (Trombotto et al., 1999; Trombotto and Borzotta, 2009). The series of soil temperatures obtained since then is the longest record of that kind in South America. A detailed monitoring process of the Morenas Coloradas rock glacier in the Central Andes registered a significant thickening of the active layer and the thawing of supra-permafrost between 1989 and 2008 (Trombotto 
and Borzotta, 2009). Remarkably, at the same time, this monitoring showed anomalies (permafrost aggradation or degradation) associated with a transient layer between the permafrost and the active layer. The present study was conducted to show how the Morenas Coloradas rock glacier is affected by global warming and how this can be detected with temperature registers (data loggers) and kinematic measurements.

It has also been taken into account that during the analyzed period there were years with an increased precipitation. This fact leads to an increased infiltration of water into the active layer and enhances the circulation of water inside this layer. Therefore the movement of the rock glacier is faster, just as described by Ikeda et al. (2008) although for a different type of cryogenic scenario.

Kinematics is defined as the quantification of movement without considering the forcing factors (Noetzli and Vonder Mühl, 2010). Kinematics takes into account different photogrammetric methods as the investigations of aerial images of different consecutive years and terrestrial geodetic surveying (eg, differential GPS measurements). These methods have already been applied in the Alps (Kääb et al., 2007; Delaloye et al., 2008; Scapozza et al., 2014; Bodin et al., 2017) in order to interpret the movement of rock glaciers as the air temperature increases. The variations of the thermal state inside the rock glacier affect its structure, which consists of cryosediments (Trombotto, 1985), but also of ice, water and air. Therefore the rock glacier speeds are varied depending on the external temperature and its local structure. It is possible to associate the monitoring points with the thermal profiles and their kinematics. Speed measurements of the different lobes on the rock glacier are being carried out to find out when motions occur and to deduce why.

This contribution presents and analyses the thermal evolution of the active layer and the different types of superficial movements produced on the most surficial structure of the Morenas Coloradas rock glacier to explain the reasons and identify what triggers these movements. At the same time it assesses how far thermal dynamics and present cryogenic phenomena incide and modify the periglacial environment, paying attention to a possible implication of these phenomena in a warming process scenario observed in the Andean periglacial environment over the last years affecting nearby human settlements.

\section{Study area}

The study area (Fig. 1) is situated in the Andean Cordillera of Mendoza, Argentina, and belongs to the "Central Andes", a region which extends between $\sim 31^{\circ}$ and $\sim 35^{\circ} \mathrm{S}$. The region corresponds to the most southern part of the Dry Andes (Lliboutry and Corte, 1998).

The studied valley is located in the basin of the Vallecitos river with a surface of $44.95 \mathrm{~km}^{2}$, a sub-basin, which is part of Morenas Coloradas $\left(16.43 \mathrm{~km}^{2}\right) 60 \%$ of which is in a periglacial environment with possible permafrost occurrence from $~ 3600 \mathrm{~m}$ a.s.l. on upwards (Trombotto et al., 1997). The maximum height of the basin surpasses $5000 \mathrm{~m}$ a.s.l. and the minimum altitude is $2500 \mathrm{~m}$ a.s.l. approximately. The study area was chosen because of its accessibility (approximately $100 \mathrm{~km}$ from Mendoza) and because it 


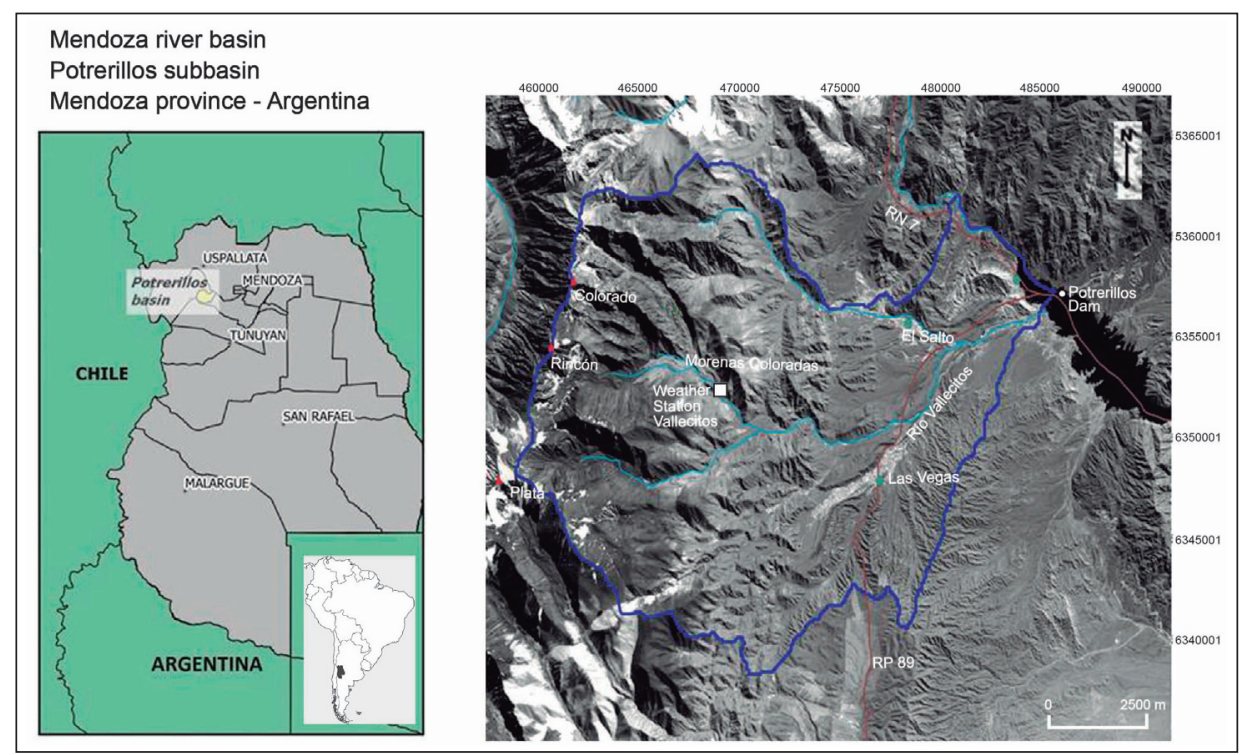

Figure 1.Study Area,SPOT4_HRVIR1_2012-02-09_13-57-30_I_675_416_SO_L2A.

was the site of regional studies (although interrupted), carried out between 1989 and 1992. The terminal part of the cryoform has been monitored continuously since 1999.

The valley of Morenas Coloradas (Fig. 1) in the Cordón del Plata mountain range, Cordillera Frontal in the Argentine province of Mendoza ( $32^{\circ} 57^{\prime} \mathrm{S}, 69^{\circ} 22^{\prime} \mathrm{W}$ ) was chosen as representative cryogenic example of that region. The valley of Morenas Coloradas has a SE orientation and is filled by a rock glacier (length $=3.7 \mathrm{~km}$; width at Balcón II = appr. $0.7 \mathrm{~km}$ ) of the tongue-shaped variety (length/width $>1$ ) according to the classification by Wahrhaftig and Cox (1959). It displays connected and superposed frozen bodies consisting of cryogenic sediments derived from morainic till. This rock glacier is of glacigenic origin that is to say that the source of the incorporated sediments is from a glacier and the debris is morainic. It is composed and multinunit because it shows superimposed lobes as well as small superimposed rock glaciers, and also multiroot, with different rooting zones from which creep and flow were identified (Barsch, 1996, Trombotto and Borzotta, 2009).

At its head the valley is also occupied by a debris-covered glacier (length $=1.4 \mathrm{~km}$ ). At present, the glacierized area has decreased considerably, almost vanished. The same is true for the surface where covered ice prevails and which ends in the rooting zone ("Wurzelzone", Barsch and King, 1989; Trombotto, 1991), where the composed rock glacier originates. The cryosediments are generated by Paleozoic rocks, mainly rhyolites from the upper Paleozoic age (Caminos, 1979), which surround the rock glacier.

The closest weather station is "Vallecitos" at $2550 \mathrm{~m}$ a.s.1. ( $32^{\circ} 59^{\prime} 12.8^{\prime}$ " $\mathrm{S}$ and $\left.69^{\circ} 21^{\prime} 21^{\prime \prime} \mathrm{W}\right)$. The collected data, however, are discontinuous. The mean annual 
air temperature (MAAT) between 1979 and 1994 was $6.3^{\circ} \mathrm{C}$ and the registered mean precipitation was $442 \mathrm{~mm}$ (1979-1983). The period between 1988 and 1992 had the highest temperatures, with a MAAT of ca. $7.4^{\circ} \mathrm{C}$.

Data of solid precipitation are scarce. Totalizers to measure rain and snowfall were installed in the study area at the sites called Vallecitos and Balcón I (3560 m a.s.1.). At Vallecitos between 1990 and 2014 (in an incomplete series) the maximum annual precipitation was $364 \mathrm{~mm}$, a value considerably below the one mentioned above. At Balcón I the annual precipitation reached $454 \mathrm{~mm}$ between 1991 and 2016 (incomplete series). This average is surpassed in years with the Niño phenomenon such as 2002 (578 mm), 2009 (589 mm) and 2015 (628 mm, a very strong Niño). The year 2003 was particularly dry with 93 and $209 \mathrm{~mm}$ registered by the respective totalizers. During summer the snow melts away quickly within days, leaving at most a layer of 5 to $10 \mathrm{~cm}$ of snow preferably at sheltered or shadowy sites.

\section{Methodology}

A periglacial and glacial map (scale 1:6000) of the basin area was made, defining areas and geomorphological units. The digitalization of the geoform Morenas Coloradas was made based on SPOT 2012 and Google Earth images. Cryogenic processes, lobes and thermokarst depressions were identified. As to direct methods, findings of permafrost (detection of permafrost through boreholes and temperature measurements) and periglacial as well as glacial ice were taken into account with the help of measurements, observations and temperature profiles made in boreholes. For the indirect methods, geoelectrical profiles and ground penetrating radar surveys were applied at the site with the collaboration of various working groups and the geocryology research unit (University of Salzburg, University of Bonn and Geomatics Unit, IANIGLA, Instituto Argentino de Nivología, Glaciología y Ciencias Ambientales, Götz et al., 2008). At the monitoring sites on the rock glacier (Fig. 2) different sensors were installed to register the soil temperature during different working periods (e.g. continuously during the periods 1989-1992, and 2004-2008: Trombotto and Borzotta, 2009). In this work, the monitoring of active layers was restarted in 2009 and finished in 2016. The monitoring sites were asssociated with temporarily installed equipment in order to study the kinematics of the sites associated to interannual and seasonal temperature changes between 2012 and 2016 and their correlation with global warming.

Climatic data are from the Vallecitos weather station and from the totalizer at Balcon I. Data from the Cricyt weather station are used for comparisons.

For this publication the data of three boreholes made on Morenas Coloradas are analyzed. These borehole sites are Balcón I, Balcón I Superior (3590 m a.s.1.), and Balcón II (3770 m a.s.1.). They have been georeferenced and their locations are part of a data file at IANIGLA belonging to global monitoring areas since 1989. Aerial photographs, satellite images and Google Earth have been used. For the monitoring, shallow boreholes (of a depth up to $6 \mathrm{~m}$ ) were drilled according to the international classification (Smith et al., 2009). These boreholes were drilled with the method developed by Hernández 


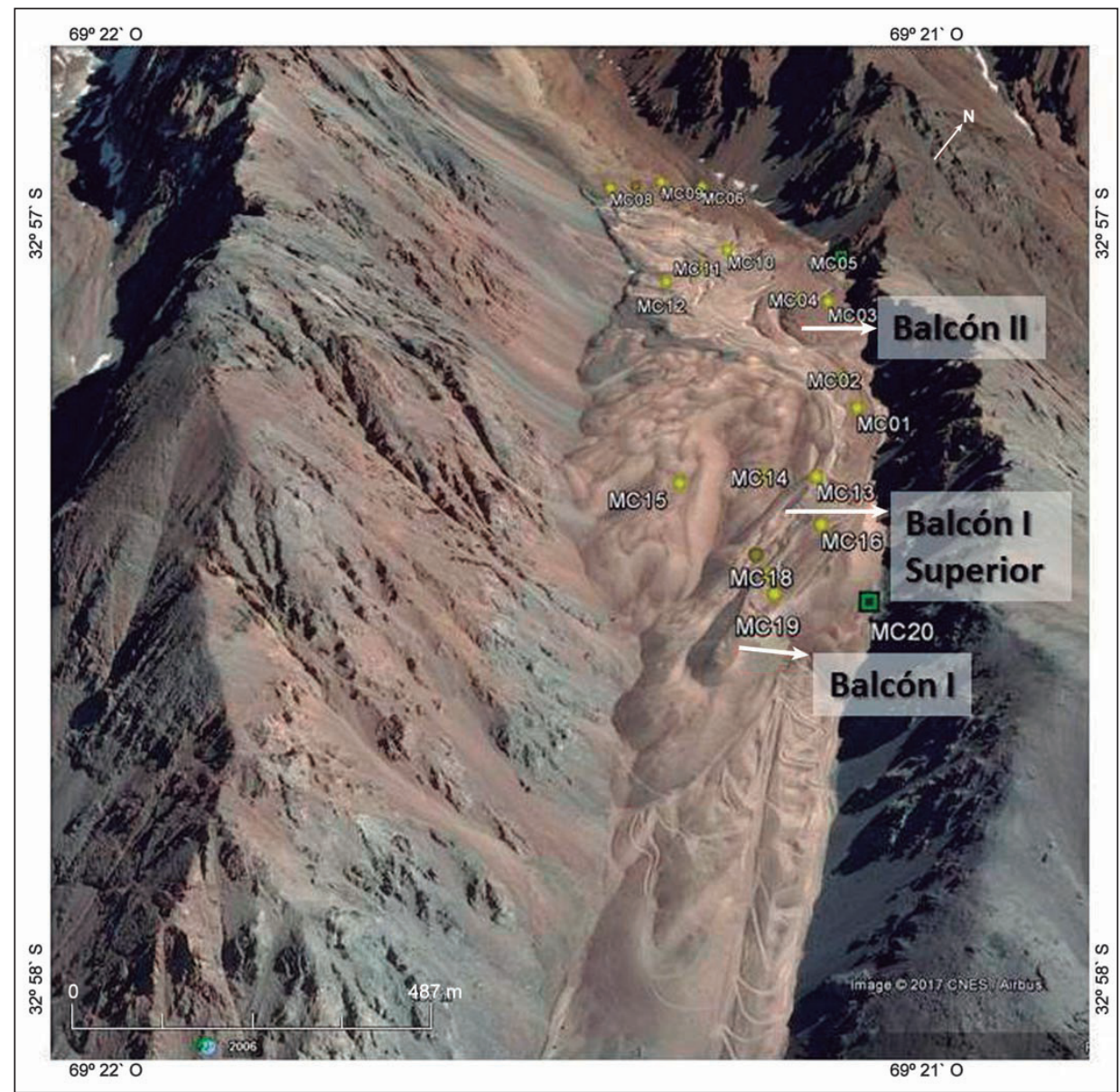

Figure 2. GPS points for kinematics and monitoring sites at Morenas Coloradas rock glacier, Google Earth, 2006.

(2002) using a percussion drill and a system of plastic pipes as a shaft in the soil to protect the incorporated sensors.

In the first borehole, Balcón I, the sensors (13) were installed in 1989 and fixed at depths of $0.05,0.20,0.70,1.20,1.70,2.20,2.70,4.00$, and $5.00 \mathrm{~m}\left(3560 \mathrm{~m}, 32^{\circ} 57^{\prime} 43^{\prime \prime}\right.$ S, $69^{\circ} 22^{\prime}$ 19' W: Fig. 2). Another borehole was drilled in 2005 and reached a depth of $5.9 \mathrm{~m}$. This helped to adjust the graphics and the temperature curves elaborated so far. A new borehole that also reached a depth of $5.9 \mathrm{~m}$ was drilled in 2006 and equipped with sensors. The data of the thermistors are read during fieldwork, mainly at the end of the summer season. These temperatures result in slash curves as seen in Figure 5.

Previously calibrated data loggers of the UTL type ( accuracy $= \pm 0,1^{\circ} \mathrm{C}$ ) built at the Unversity of Bern (Switzerland) were installed in the boreholes at Balcón I 
Superior and Balcón II. Balcón I Superior (3589 m, 32 57' 18” S, 69 22’ 14” W: Fig. 2) includes two boreholes for thermistors (8) performed nearby, delivering data since 2008. In the first borehole, sensors were installed depths of 2,3,4 and $4.7 \mathrm{~m}$ and in the second at depths of 1.2 and $3.25 \mathrm{~m}$. The data and graphics were obtained and completed from different equipment such as thermo-sensors and UTL data loggers. The data loggers were installed at depths of 3.25 and $4.7 \mathrm{~m}$ and collected data every 4 hours. These data are complemented by data obtained from the thermistors read at late summer.

At Balcón II (3770 m, 32॰ 56’ 95” S 69²2’ 49” W: Fig. 2) the UTL sensors were placed at depths of 1.5 and $3 \mathrm{~m}$ depth in 2001 . The depth of $3 \mathrm{~m}$ coincides with the permafrost table of 2001, when the monitoring of this site began. The measured temperatures were corroborated by new boreholes and recent measurements.

In order to measure the motions in different lobes of the rock glacier Morenas Coloradas, GPS receivers with double-frequency Trimble 5700 and TrimbleNetRs were used. Six mobile points were chosen: MC18 and MC19 at Balcón I; MC13 at Balcón I Superior; MC3 and MC4 at Balcón II; and MC15 on an inactive lobe of the rock glacier. These points were chosen carefully in order to obtain the best possible measurements from inside the rock glacier but also close to areas with already existing subsoil temperature registers (Balcón I, Balcón I Superior and Balcón II), so that a correlation between the movement and the temperature graphics could be established (Fig. 2).

The kinematic values of the velocities are shown according to the consecutive number of days analyzed per year: they are not averaged over 365 days. This is to maintain the accuracy of the values with this method. The velocities were measured during four different periods: October 2013 - May 2014; May 2014 - November 2014; November 2014 - May 2015 and May 2015 - February 2016. These periods could not always be completed for climatic reasons. For this reason the velocities are analyzed in $\mathrm{cm}$ per month in order to maintain accuracy. GPS equipment was installed in the field. The long-term kinematic calculation that is presented in this paper is made for the first time in South America. There is little information worldwide about such calculations in periglacial regions. The aim is to reach accuracy values.

The size of the boulders where the points are, has been analyzed. These boulders would move accordingly with the movement of the rock glacier. Once the boulders of the lobes to be monitored were chosen, the rock was then perforated with a battery-driven drill and anchors were fixed with glue so that they would remain attached to the rock. On the anchors a turning tray holding the GPS antenna was fixed. The antennas used in this case were Trimble Zephyr TRM39105 and Trimble Zephyr Geodetic TRM41249. The turning tray allows the antenna to direct northwards in order to guarantee a repetition in equal conditions of data collection through time.

Blocks on the rock glacier are large $\left(>1 \mathrm{~m}^{3}\right)$ and apparently stable (see Lambiel and Delaloye, 2004). There are no slight movements of the active layer caused by seasonal processes. The blocks were registered on images and photographs during several consecutive years. In some cases, they were found on the edge of lobes or active areas 
detected by transverse arc shaped ridges and furrows (structuralization of the superficial sediments or facies with patterned debris of Corte, 1976a).

The applied GPS method is called static and differential (Little et al., 2003). Measurements are made relative to a base line and a point which is supposed to be moving. Both receptors store data in memory. The base corresponds to continuous stations located in different countries (BRAZ; CSJ1; MZAC; MZAL; PARC; UNAS) and the "rover" to 20 points, two of which named MC05 and MC20 are outcrops near the rock glacier and therefore are fixed and serve as reference. Once the GPS equipment is installed in the field it remains at each monitoring site for 48 hours. The general precision of the equipment for the calculated time gives a range of 1.9-6 mm. The calculations of the movements in $\mathrm{S}$ and E directions showed a precision (RMS = root-mean-square error) between 1 y $8 \mathrm{~mm}$, but in vertical movement however it was between 5 and $24 \mathrm{~mm}$ (Bennett, 2007).

Afterwards, all data are processed with the Bernese GNSS software, a scientific high-precision program developed by the Astronomical Institute of the University of Bern (AIUB). On the basis of the data processing, movement vectors are created. These vectors, if found, give evidence of the direction and orientation of the creeping of permafrost and also of the active layer.

The speed calculation in this work is based on reliable data obtained over a period of more than two years, as established by Blewitt and Lavallée (2002), but with the difference that a long-term kinematic calculation, of 48 hours is used for the selected points. This method gave a high accuracy. No previous references of this technique have been found.

The correlation between the movement and the temperature graphics at Balcón I could not be established. These were single temperature measurements and obtained on the spot with the help of thermistors installed at depth with electrical multimeter equipment. This procedure was followed in each summer campaign and where possible throughout the year.

\section{Results and Discussions}

\subsection{Mapping of the Morenas Coloradas rock glacier}

The major part of the Morenas Coloradas rock glacier has been studied thoroughly with numerous direct and geophysical methods and was defined as a rock glacier by various authors years ago (Barsch and King, 1989; Barsch 1996; Götz et al., 2008; Trombotto and Borzotta, 2009; Halla et al., 2018).

The Morenas Coloradas rock glacier was presented in the inventory and cartography of rock glaciers of the Cordon del Plata, Central Andes of Mendoza with LANDSAT images 2000 in 2003 (Trombotto, 2003)

Figure 3 shows the different cryomorphic units that can be identified in the Morenas Coloradas rock glacier and also the kinematic calculation points that are being used. The glacigenic rock glacier Morenas Coloradas can be distinguished from the debris covered glacier also called Morenas Coloradas by various indicators. One important element for 


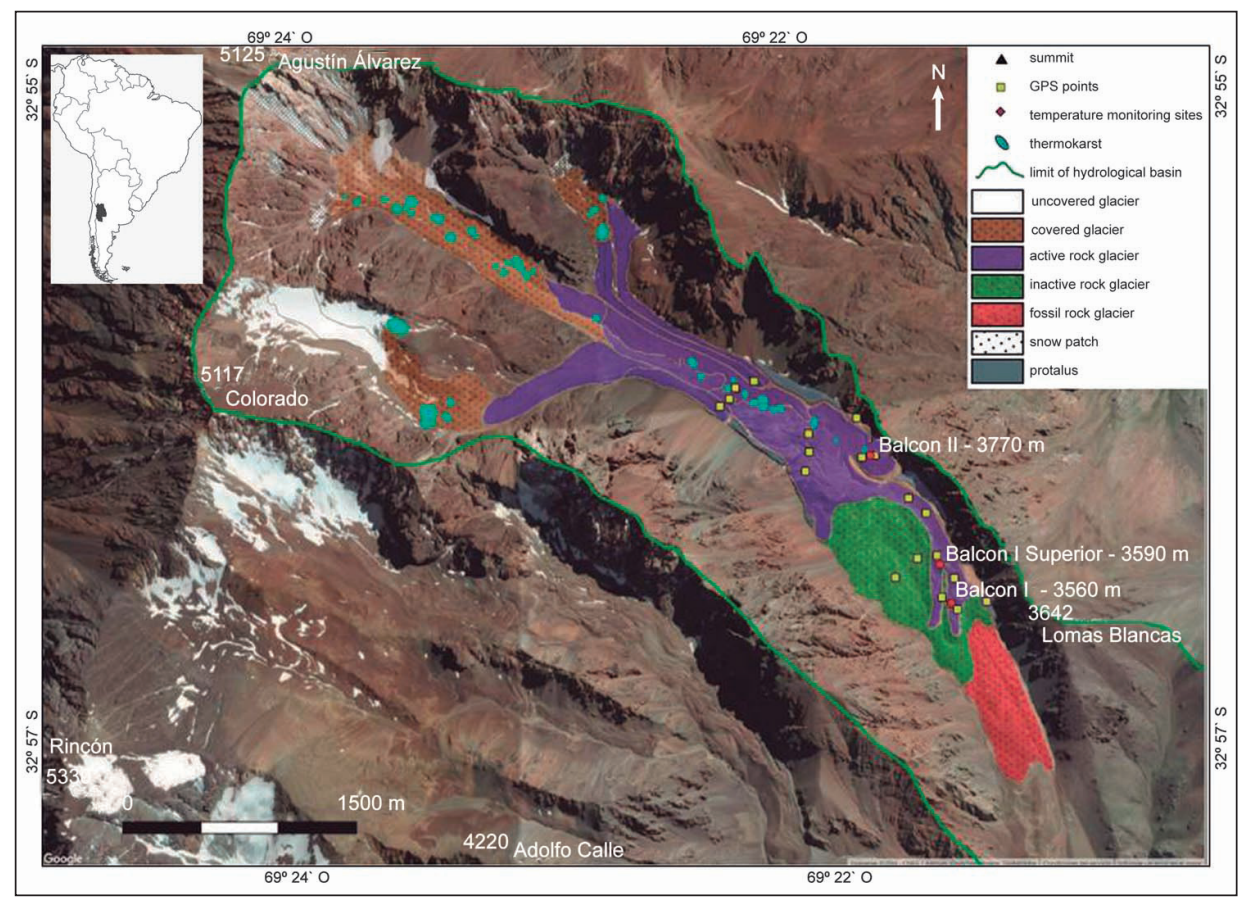

Figure 3. Monitoring sites and geocryology of the Morenas Coloradas rock glacier, Google Earth, 2006.

this distinction in fieldwork is the fact that the debris covered glacier contains ice under a relatively thin layer of sediments displaying a chaotic structure.

The ice is found at little depth -that is to say, with a cover of cryosediments less than one meter in thickness. It is ancient ice, stratified and with a thickness in the interior of the thermokarst figured to measure 10-20 m, protected by the cold south slope of the valley (Fig. 4). This area of debris-covered glacier in the Central Andes presents a high density of thermokarst depressions with visible ice caused by processes of ice degradation due to climatic variability. The rock glacier, however, is generated from a transitional part of the debris-covered glacier where a structuralization of the sediment layers becomes clearly visible, with flow arches, furrows parallel to the movement, independent or superposed lobes, and superficial periglacial phenomena and forms (patterned ground, solifluction forms). Thermokarst depressions are isolated in this case, indicating rests of subterranean ice as well at greater depth and disconnected from the original body of glacigenic origin.

The central part of the cryoform, in a zone with subterranean glacial ice possibly injected and/or incorporated as islands into the cryoform, shows degraded parts and thermokarst. The zone with glacial ice seems to determine and strongly influence the subsequent geomorphological lobe below. It has well pronounced arches at the site Balcón II, although this lobe is marginal. The lobe with exposed ice in the thermokarst 


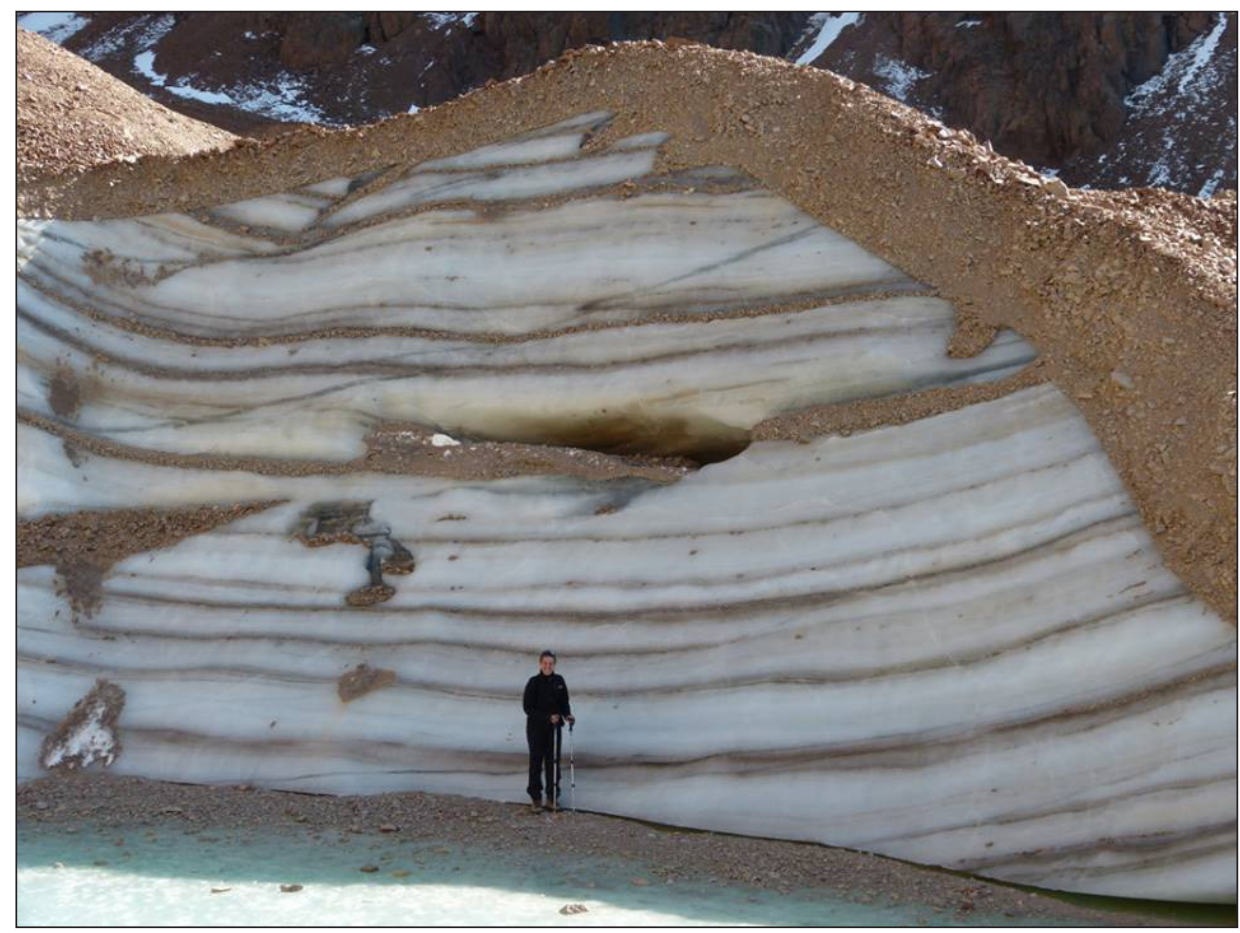

Figure 4. Naturally exposed section showing thermokarst depression and glacial ice in the Morenas Coloradas valley, part of debris covered glacier.

also influences the neighboring cryogenic lobe in the $\mathrm{S}$, where the parallel furrows of cryosediments that already begin in the area of the covered glacier at much higher altitude, start to deform slope downwards.

The fact that the thermokarst at a distance of approximately $1 \mathrm{~km}$ from the rooting zone are exposed to the air and their glacier ice is melting provides water infiltration and circulation in the middle sector of the cryoform and favours a faster movement of the rock glacier in the sense of Ikeda et al. (2008) and Lambiel (2011).

4.2. Analysis of the evolution of the active layer at the monitoring sites Balcón I, Balcón I Superior and Balcón II since 2008

\subsubsection{Balcón I}

The site is located in a slightly sunken terraced zone close to a superimposed active lobe at higher altitude.

Figure 5 shows the different soil temperature curves in front of the rock glacier Morenas Coloradas elaborated on the base of the data collected with thermistors buried into the ground at a depth of up to $\sim 6 \mathrm{~m}$. This figure displays the varying thickness of 


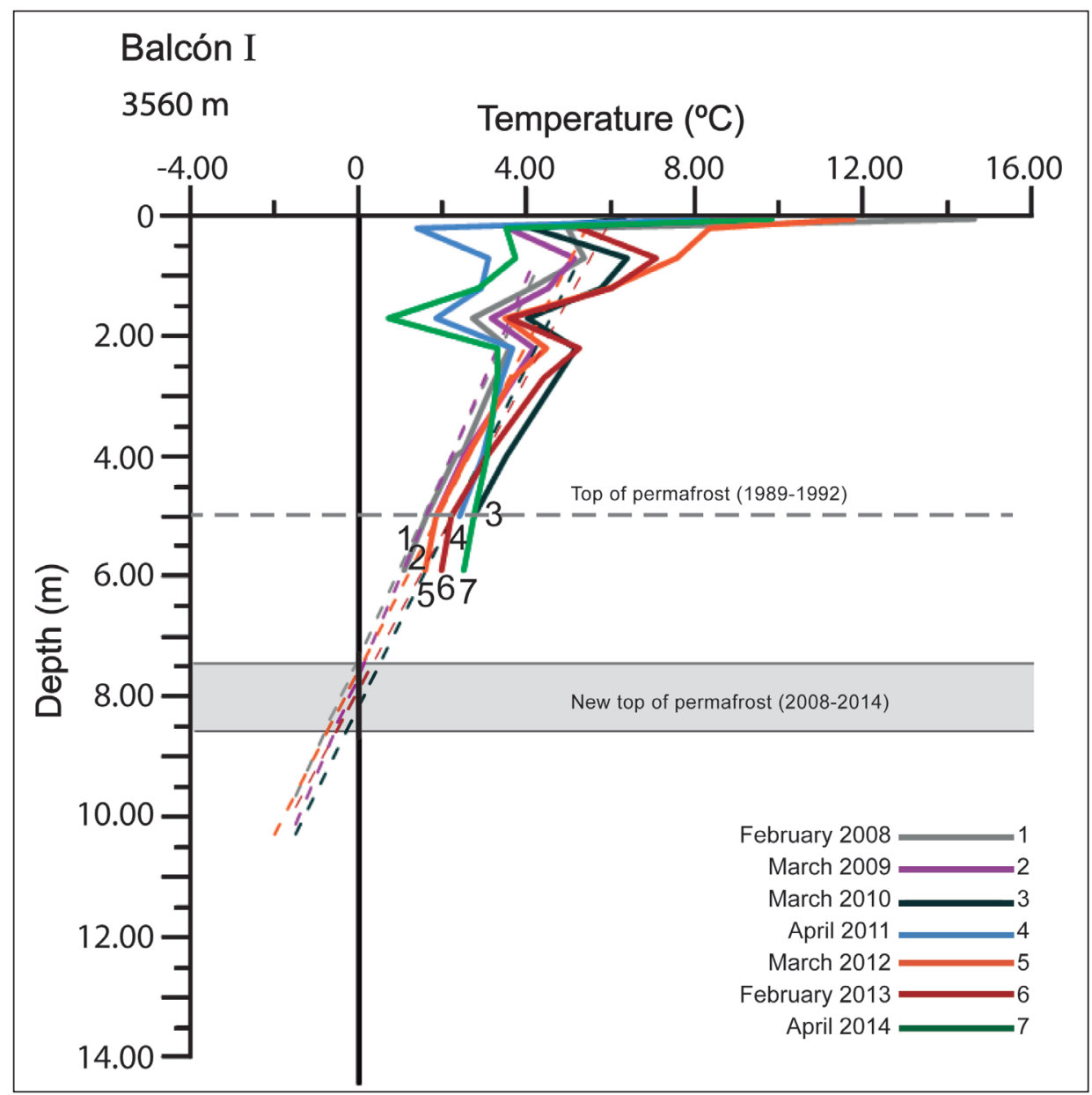

Figure 5. Evolution of the active layer at Balcón I, data of the thermistors (end of summer season).

the active layer calculated with the determination of the permafrost table. The curves include data from the end of the respective summer seasons and were read at similar times in the years 2007/2008, 2008/2009, 2009/2010, 2010/2011 and 2011/2012. The years $2014 / 2015$ and $2015 / 2016$ are shown in Table 1 . The temperature values obtained by thermistors are from the end of the summer season.

Figure 5 shows the extrapolation of the temperature curves, the depth of which was also adjusted with a linear regression in order to model the dependence of the variables at greater depth and to observe where the isotherm of $0^{\circ} \mathrm{C}$ is intersected (zone in grey), once below the $6 \mathrm{~m}$ depth reached by the thermistors. The correlation coefficient used was generally larger than 0.85 . 


\begin{tabular}{|c|c|c|c|c|}
\hline 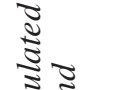 & 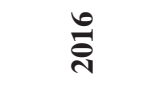 & $\stackrel{\infty}{\sim}$ & $\frac{\theta}{i s}$ & $\stackrel{\sim}{m}$ \\
\hline $\begin{array}{l}\vec{z} \\
\tilde{U} \\
\vec{z} \\
\vec{z}\end{array}$ & $\frac{n}{8}$ & $\stackrel{\infty}{\sim}$ & $\begin{array}{l}\infty \\
\dot{v}\end{array}$ & $\stackrel{\sim}{m}$ \\
\hline 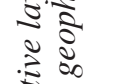 & 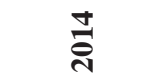 & $\frac{\partial}{i n}$ & $\overrightarrow{6}$ & $\stackrel{m}{m}$ \\
\hline 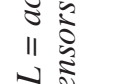 & $\stackrel{m}{\bar{\pi}}$ & $\stackrel{r}{r}$ & $\begin{array}{l}\dot{r} \\
\dot{n}\end{array}$ & $\stackrel{\sim}{m}$ \\
\hline : & 골 & $\underset{r}{\stackrel{r}{r}}$ & $\underset{i}{\dot{r}}$ & $\stackrel{\sim}{m}$ \\
\hline $\begin{array}{cc}0 \\
0 \\
0 \\
0 \\
0\end{array}$ & $\overline{\bar{乛}}$ & $\frac{2}{i n}$ & $\ddot{n}$ & $\vec{m}$ \\
\hline$\frac{7}{3} \frac{3}{3}$ & 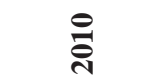 & $\stackrel{m}{\infty}$ & $\stackrel{\forall}{\dot{n}}$ & $m$ \\
\hline 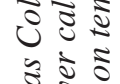 & ્ેㄱ & $\stackrel{\infty}{\sim}$ & $\ddot{n}$ & $\stackrel{\sim}{m}$ \\
\hline 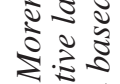 & હ્సે & $\stackrel{n}{r}$ & $\vec{n}$ & $m$ \\
\hline 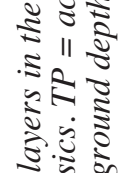 & 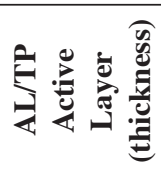 & 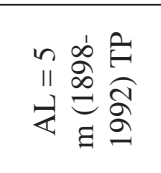 & 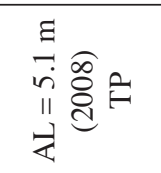 & 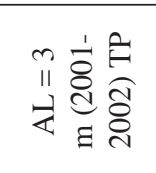 \\
\hline 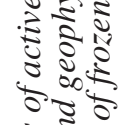 & 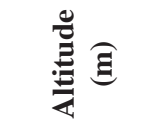 & $\begin{array}{l}8 \\
\text { n } \\
m\end{array}$ & $\begin{array}{l}\infty \\
\infty \\
m\end{array}$ & 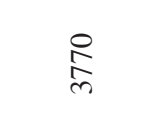 \\
\hline 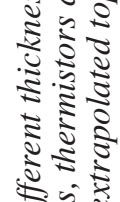 & . & 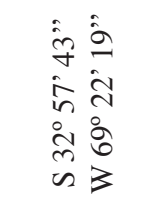 & 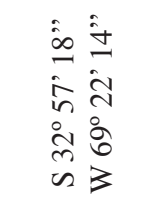 & 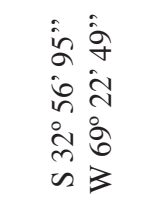 \\
\hline $\begin{array}{l}0 \\
\frac{2}{2} \\
0 \\
0 \\
0 \\
0 \\
0 \\
0\end{array}$ & 营 & 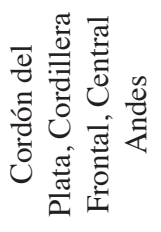 & 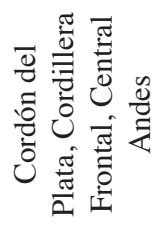 & 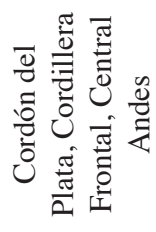 \\
\hline 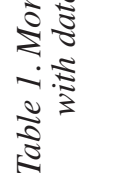 & 梯 & ש & 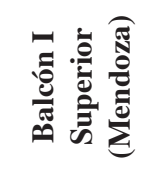 & 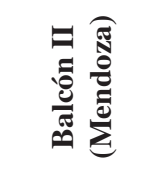 \\
\hline
\end{tabular}


The tendency of the curves for the analyzed period reveals that the extrapolation of the temperature curves at the end of the summer season, when we registered the warmest temperatures that delimit the active layer, was never again found at a depth of $5 \mathrm{~m}$ at $3560 \mathrm{~m}$ a.s.1., as it used to be until the end of the 1990s (Trombotto et al., 1999). This tendency is similar to that observed at the beginning of the year 2000 and shows the evolution of the active layer also within a transient layer (Trombotto and Borzotta, 2009). Long-term studies showed that the $0{ }^{\circ} \mathrm{C}$ isotherm is higher in altitude than the active front of the rock glacier and it has risen $40 \mathrm{~m}$ in altitude (at Balcón I Superior, $3600 \mathrm{~m}$ a.s.1. approximately) since the 1990s.

At $2 \mathrm{~m}$ depth, the curves showing the thermal offset were earlier described by Burn and Smith (1988) and interpreted according to the lithological and humidity variations of the profile. It is assumed that at $2 \mathrm{~m}$ depth there is a layer with fine sediments that retains more moisture from melting water and has a high specific heat capacity, and therefore greater thermal inertia, which impedes a continuous and gradual decrease of temperature.

It has been stated that already from April onwards, after the summer, it becomes difficult to interpret what happens to the temperature curve at depth. Possibly in autumn, with the first and discontinuous important frost in the first meters of the active layer, the heterogeneity of the sedimentary profile influences the values taken with the thermistors. In April there is increased precipitation, sometimes as rain and sometimes combined with snow which affects the active layer thickness and complicates the measurement of the permafrost table.

The thickness of the active layer was 7.4-7.5 m for the year 2008, which represents a thinning compared to the previous 9 years (1999-2007). Subsequently the active layer gained thickness again and reached $8.3 \mathrm{~m}$ in the year 2010. That can be explained by the fact that 2010 was a Niño" year, with abundant precipitation (snowfall and rain). This history was consistent with the results from Balcón I Superior, located on the same lobe but at a higher altitude. The thickening was interrupted in 2012, which was a particularly warm year with a high MAAT (Regional Center of Science and Technology, Mendoza = CRICYT weather station, $827 \mathrm{~m}$ a.s.1., 32 ${ }^{\circ} 53^{\prime} \mathrm{S}$ and $\left.68^{\circ} 51^{\prime} \mathrm{W}\right)$. It seems that melting water in the active layer degrades the top of the permafrost during the summer and can also cause the deepening of the frozen layer. After 2012, the two curves were similar, indicating thickening not exceeding $7.8 \mathrm{~m}$ at Balcón I (Table 1).

Regarding geomorphological characteristics (reduction of the front angle, softened relief, inactive thermokarst) this rock glacier front at Balcón I has entered a transition phase towards inactivity. The active layer is thick and considering its diffusivity $\left(\alpha=0.17 \times 10^{-6} \mathrm{~m} \mathrm{~s}^{-1}\right.$ : Trombotto and Borzotta, 2009) its basal depth ought to be related only to long-term changes, perhaps in the annual-decadal order.

In the last ten years however, there were changes in the open structure of the rock glacier within the period that could be associated to the influence of subterranean melting water discharge during summer, or to peaks of increased discharge caused by years with increased snowfall (2009/2010 and 2015/2016) (Trombotto Liaudat et al., 2008). 
This monitoring site might be considered to be on a thermal talik in a rock glacier -an unfrozen zone between active lobes.

\subsubsection{Balcón I Superior}

This monitoring site is located approximately 40 m higher than Balcón I (Fig 3) and situated on an active lobe with signs of mass wasting at its front (e.g. falling clasts could be observed during summer field work) and patches of humidity where seasonal ice had melted, leaving profiles of fine sediment exposed.

The site reflects the climatic variability observed at Balcón I in the 1980s (Trombotto et al., 1999; Trombotto and Borzotta, 2009), that is to say an active layer of approximately $5 \mathrm{~m}$ thickness when first detected by temperature measurements in equipped boreholes. The base of the active layer was corroborated indirectly with the help of a GPR equipment (Götz et al., 2008).

At this site boreholes of up to $5 \mathrm{~m}$ depth were drilled and the shaft was equipped with data loggers and thermistors in order to measure differences or similarities of the data obtained from the different superficial pits. As in the former case, linear regressions allowed us to adjust the permafrost table value as well as the thickness of the active layer. The applied correlation coefficient was 0.98/0.99. After the year 2008, when the holes were drilled, a deepening of the active layer base by $\sim 10 \mathrm{~cm}$ per year was registered until the year 2012 (Fig. 6A and Fig. 6D, Table 1).

Figure 6B from 2009 also shows that the depth of the convergence of minimum and maximum temperatures (apparent zero annual amplitude) and the permafrost table is similar to that observed in 2012 (Fig. 6C) despite the deepening of the permafrost table. As before, in this case the line to cut the apparent annual zero amplitude level was figured by a prolongation of the mean temperatures from the month of August. July and August are the months with the lowest air temperatures. It has to be pointed out however, that sub-zero ground temperatures often persisted during the months of September and October and the curves may coincide. In 2013 (Fig. 6D) the equipment could not read the winter temperatures, and in 2014 the summer temperatures. Therefore these values could not be represented. The active layers (2014 and 2015) were calculated through the mean temperature of the warmest month. At the same time the thickness of the active layer was calculated with the help of thermistors of another borehole and adjusted with a linear regression.

In 2010, the above described thickening of the active layer in Balcón I was also observed at Balcón I Superior, but the maximum depth was detected between 2014 and 2015, reaching a thickness of $6.1 \mathrm{~m}$. The horizon of apparent zero annual amplitude measured also deepened by $20 \mathrm{~cm}$, below that there is practically no annual fluctuation in ground temperature. This fast deepening can be explained by the fact that the caloric wave found a layer of major thermal conductivity $(\mathrm{K})$ and/or one that possesses little apparent caloric capacity $(\mathrm{C})$. A positive mean annual ground temperature (MAGT) was registered with a thermistor at $4.9 \mathrm{~m}$ depth in 2014 and this fact coincides with the registration of a slight increase of the MAAT between 2012 and 2015 in the city of 


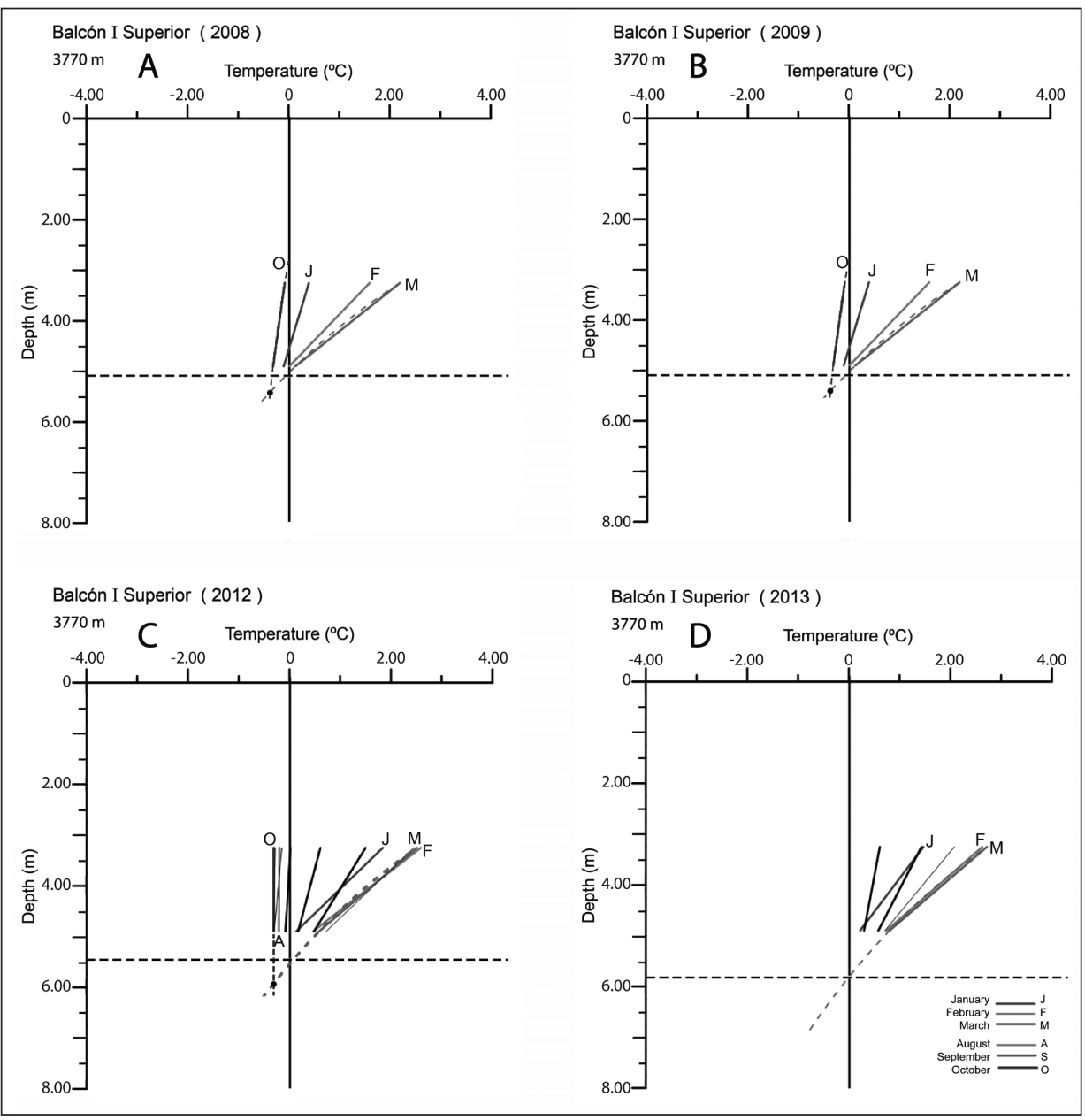

Figure 6. Evolution of the active layer in Balcón I Superior in different years. The lines without letters correspond to the intermediate months, the dotted line indicates the permafrost table.

Mendoza and at the CRICYT station. It is very important to mention that in 2015-2016 there was a very strong Niño, associated with more snow in the Central Andes.

The site is situated on a planation surface /small plateau on an active lobe, which allows us to rule out the influence of subterranean water flow from positive small geoforms on the surface of a nearby rock glacier. This physical balance compels to pay more attention to the balance between air and soil temperature. This is consistent with the regional temperature rise registered by Rosenblüth et al., 1997, Jones and Moberg, 2003, and UNEP, 2007. 


\subsubsection{Balcón II}

Balcón II is the highest monitoring site of the Morenas Coloradas rock glacier. It is also the site where the active layer appears to be thinnest (Trombotto and Borzotta, 2009). In Figure 7A to Figure 7D the curves of the warmest and coldest months of the subsoil at Balcón II are shown. According to the graphical representation, the horizon of apparent zero amplitude of the respective year and the thickness of the active layer can be observed.

The warming process detected since the early summer of 2008 does not show significant changes over the analyzed period, on the contrary, mean annual ground temperatures (MAGT) are all negative at a depth of $3 \mathrm{~m}$ and in 2010 and 2011close to $\left.-0.5^{\circ} \mathrm{C}\right)$. It has to be mentioned that until 2007 the site indicated a deepening of the active

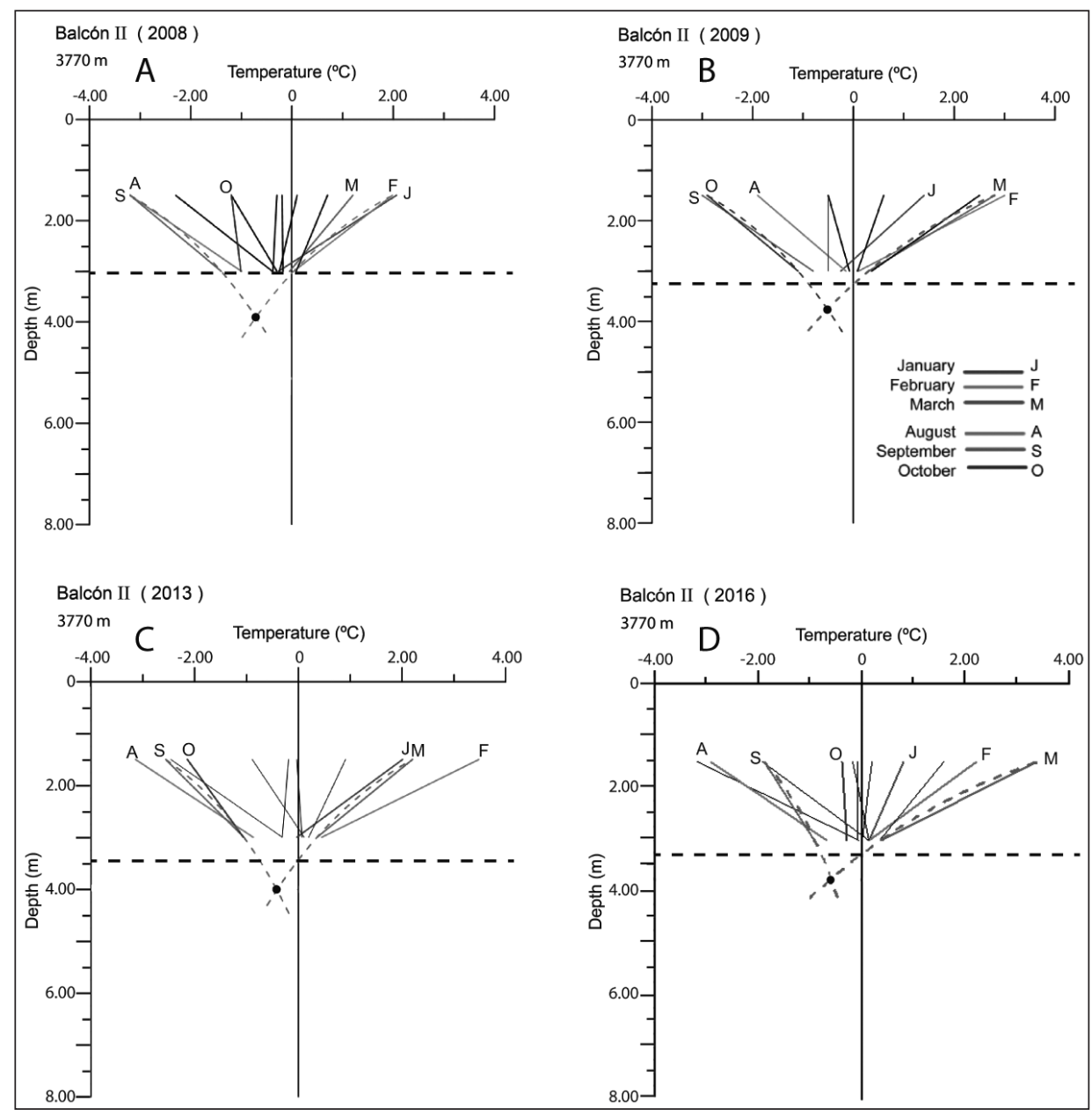

Figure 7. Evolution of the active layer at Balcón II. The lines without letters correspond to the intermediate months, the dotted line indicates the permafrost table. 
layer by $10-30 \mathrm{~cm}$ due to the warmer temperatures during summer between January and March was figured to be at a depth of $3 \mathrm{~m}$ in 2001 when the borehole was drilled. However, the MAGT at a depth of $3 \mathrm{~m}$, was approx. $-0.31^{\circ} \mathrm{C}$ between 2004 and 2007 (Trombotto and Borzotta, 2009). In 2007 which was an exceptionally cold year, it was $-0.46{ }^{\circ} \mathrm{C}$. The horizon of zero amplitude was found at approximately $3.9 \mathrm{~m}$ depth during those four years.

In 2008 (Fig. 7A) the permafrost table does not seem to have undergone significant changes compared to 2004-2007 and the MAGT between 2008 and 2011 at 3 m depth was practically unchanged. At the beginning of 2012 however, the positive summer temperatures (January-March) intersected the $0^{\circ} \mathrm{C}$ isotherm below $3 \mathrm{~m}$, from which a gradual deepening of about $10 \mathrm{~cm}$ per year may be inferred. The MAGT at $3 \mathrm{~m}$ depth, however, has always been negative.

In 2013 (Fig. 7C) the MAGT at $3 \mathrm{~m}$ depth reached $-0.1 /-0.2^{\circ} \mathrm{C}$, which is within the accuracy limitation of the equipment. A marginally subzero temperature means, that the top of the permafrost did not have any variation. The illustration of the warmest month until present, creates a cut of the curve at ever-increasing depth just like in 2014, a year in which the equipment failed resulting in an incomplete record. From 2008 to year 2014 the warmest month (March) intersected the zero isotherm at increasing depth. The phenomenon occurred within a transient layer.

While the horizon of apparent zero annual amplitude during 2008-2016 remains at a depth between 3.75 and $4 \mathrm{~m}$ (Fig. 7B, Fig. 7C and Fig. 7D), the permafrost table was at a depth between 3.2 and $3.3 \mathrm{~m}$ (Table 1) where the active layer showed thickening.

From the statements above it may be deduced that the variations found at the depth where the curve intersects the $0^{\circ} \mathrm{C}$ isotherm, correspond to changes in the transient layer of the site. These changes have to be considered a temporary phenomenon for now, though with a clear tendency to warming at a depth of $3 \mathrm{~m}$ (Fig. 8).

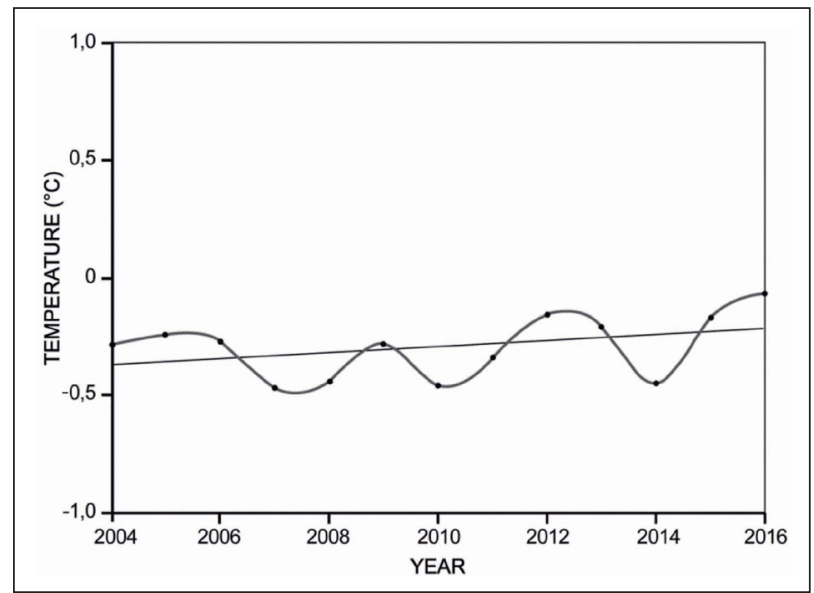

Figure 8. MAGT variations at $3 m$ active layer depth at Balcón II. 


\subsection{Kinematics}

Some authors used the fast static methodology to calculate kinematic measurements of rock glaciers. Lambiel and Delaloye (2004) and Delaloye et al. (2010) for example, used this methodology in the Swiss Alps. In the same way, Bodin and Trombotto (2015) used fast static techniques it in the Argentine Central Andes, and Martini et al. (2014) in the Cordillera Oriental of Argentina. Delaloye et al. (2010) obtained displacements of up to $3 \mathrm{~m}$ per year between the years 2001 and 2009. It should be mentioned that unlike this work that uses long baselines $(>20 \mathrm{~km})$, the authors used short baselines $(<20 \mathrm{~km})$.

Kinematics in the Morenas Colorads rock glacier were related to the three monitioring sites (Fig. 2) and were represented in different axes or orthogonal directions. The rock glacier at the three monitoring stations flowed at different velocities, both from station to station and also directionally: vertical ("velocity down, or VD), and East (VE) and South (VS). VE and VS are parallel to the terrain (and VS is parallel to the general slope of the valley) (Table 2).

Table 2. Kinematic monitoring points and their velocities.

\begin{tabular}{|c|c|c|c|c|c|}
\hline \multicolumn{6}{|c|}{ Velocities (cm/month) } \\
\hline Station & Typ & $\begin{array}{c}\text { Period 01-02 } \\
\text { Oct 2013-May } 2014\end{array}$ & $\begin{array}{c}\text { Period 02-03 } \\
\text { May 2014 - Nov } 2014\end{array}$ & $\begin{array}{c}\text { Period 03-04 } \\
\text { Nov 2014 - May } 2015\end{array}$ & $\begin{array}{c}\text { Period 04-05 } \\
\text { May 2015 - Feb 2016 }\end{array}$ \\
\hline \multirow{3}{*}{$\mathrm{MC03}$} & V-Up & 0.88 & 0.84 & 2.15 & 3.10 \\
\hline & V-South & 4.45 & 4.32 & 3.78 & 3.63 \\
\hline & V-East & 3.97 & 3.39 & 3.98 & 3.17 \\
\hline \multirow{3}{*}{ MC04 } & V-Up & 0.75 & 1.23 & 2.32 & 3.15 \\
\hline & V-South & 3.70 & 3.45 & 2.98 & 2.81 \\
\hline & V-East & 1.42 & 1.19 & 1.25 & 0.83 \\
\hline \multirow{3}{*}{ MC13 } & V-Up & 0.72 & 0.64 & 2.42 & 2.78 \\
\hline & V-South & 3.36 & 2.87 & 2.30 & 1.86 \\
\hline & V-East & 0.97 & 0.87 & 0.88 & 0.60 \\
\hline \multirow{3}{*}{ MC15 } & V-Up & & & 4.34 & 2.26 \\
\hline & V-South & & & -1.08 & -0.82 \\
\hline & V-East & & & -0.12 & -0.37 \\
\hline \multirow{3}{*}{ MC16 } & V-Up & 6.43 & 4.70 & 8.18 & 8.40 \\
\hline & V-South & 25.21 & 22.55 & 24.64 & 24.00 \\
\hline & V-East & 1.96 & 1.94 & -2.81 & -3.21 \\
\hline \multirow{3}{*}{ MC18 } & V-Up & & & 8.29 & 9.16 \\
\hline & V-South & & & 20.29 & 19.72 \\
\hline & V-East & & & 2.68 & 2.20 \\
\hline \multirow{3}{*}{ MC19 } & V-Up & & & 4.17 & 6.46 \\
\hline & V-South & & & 20.22 & 19.77 \\
\hline & V-East & & & 2.40 & 1.95 \\
\hline
\end{tabular}

Table 2 shows the velocities that were measured in the field. The velocities of points MC 18 and MC 19 were measured near the site Balcón I (at a distance of $10 \mathrm{~m}$ and $60 \mathrm{~m}$ respectively) and they are closely linked with them. Unfortunately MC 18 and MC 19 data were obtained of only two periods due to bad weather conditions. 


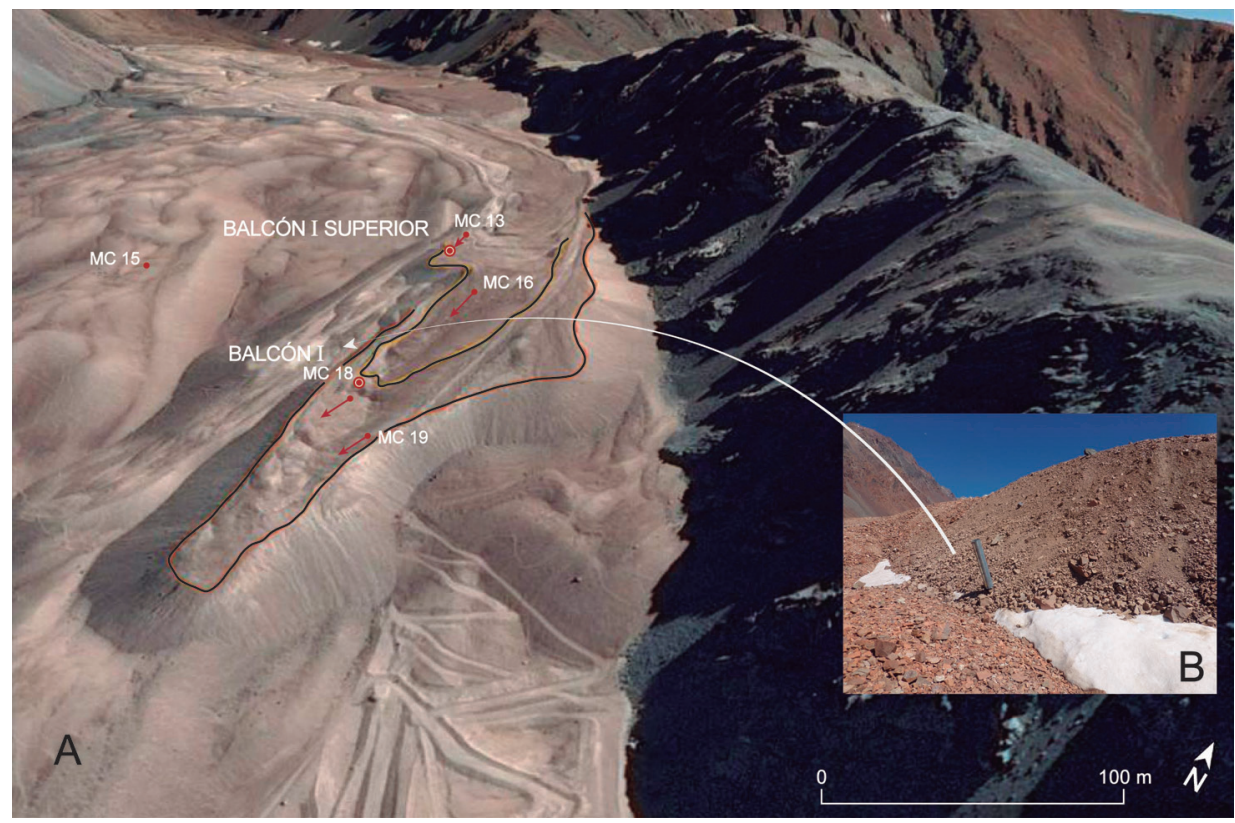

Figure 9. GPS points for kinematics at Balcón I and Balcón I Superior. B = Totalizer at Balcón I.

VS velocities at both MC 18 and MC 19, are higher than VE indicating a great displacement valley down. VS towards the south is similar for both points (appr. $2 \mathrm{~m} / \mathrm{year}$ ) and among the highest velocities registered in the kinematic monitoring of the cryoform, which is related to the maximum deepening of the active layer or its transformation into a talik (Fig. 5, Table 2). VE and VD behaved similar to the rest of the rock glacier. This behavior is accompanied by a significant velocity VD (Table 2). The change between the maximum depth of the permafrost table calculated in 2015 is consistent with the calculated temperatures.

The monitoring point MC15 is located in an inactive zone and, as can be observed in table 2, the values indicate little movement attributed to active layer processes. VD is indicating movements related to frost heave and sediment displacements. The data validate the geocryological interpretation of the area (Fig. 3).

Kinematics of Balcón I Superior were analyzed through points MC 13 and MC 16 (Fig. 9, at a distance of $56 \mathrm{~m}$ and $133 \mathrm{~m}$ respectively from Balcón I Superior). The points show an increase of velocity at depth (VD) particularly point MC16. This vertical increase at VD is likely to be related to the deepening of the active layer at Balcón I Superior, discussed above (4.2.2). Compared with MC 16, MC 13 (Table 2) indicates low velocities at VS and VE. In this particular case VD increases, from Oct. 2013 to Feb. 2016 This coincides with the increased temperature observed in the curves for 4.7 and $3.25 \mathrm{~m}$. VS and VE, however, decrease over this same period, although the change in VE was small. The decrease in VS was homogenous and observed during all measuring periods. 
Point MC 16 (Fig. 10) is situated farther south of the monitoring site for the soil temperatures near Balcón I Superior. It registers a velocity increase in all directions. VE was negative and VS was at most 2 m per year (Table 2) from May 2015 to February 2016, consistent with the great activity of the lobe at Balcón I Superior and with the movement described and observed during field campaigns. This part of the lobe advanced over Balcón I and tumbled the totalizer (Fig. 9B).

Balcón I and Balcón I Superior are located at the final part of the rock glacier and close to its front. The active front is interdigitated and stopped by an area with inactive lobes. For this reason it does not reflect the horizontal movements of Balcón I Superior.

At Balcón II, MC03 and MC04 (Figs. 11 and 12) are the most important kinematic points to be analyzed because of their proximity (appr. $50 \mathrm{~m}$ ) to the monitoring site and because they can be correlated to the occurrences at the profile of soil temperatures.

VD increased at both points, especially from November 2014 onwards, likely in response to the observed warming. VS, however, decreased while VE oscillated between periods of increase and decrease during this same time (Figs. 11 and 12, Table 2). In the last period, May 2015 - Feb 2016 all three velocities had become similar at MC3, with VS exceeding VD and VE, which were similar in magnitude. In general MC3 moved to the east and south (because of the general orientation of the lobe, which is SE). The VE at MC3 is three times more than MC4 which, showed lower velocities because it is on the border and because it is the biggest block of all. In general MC4 moved southwards.

So far it has been assumed that a temperature rise is the most important factor of climatic variability that determines that the superposed lobes and the front of this

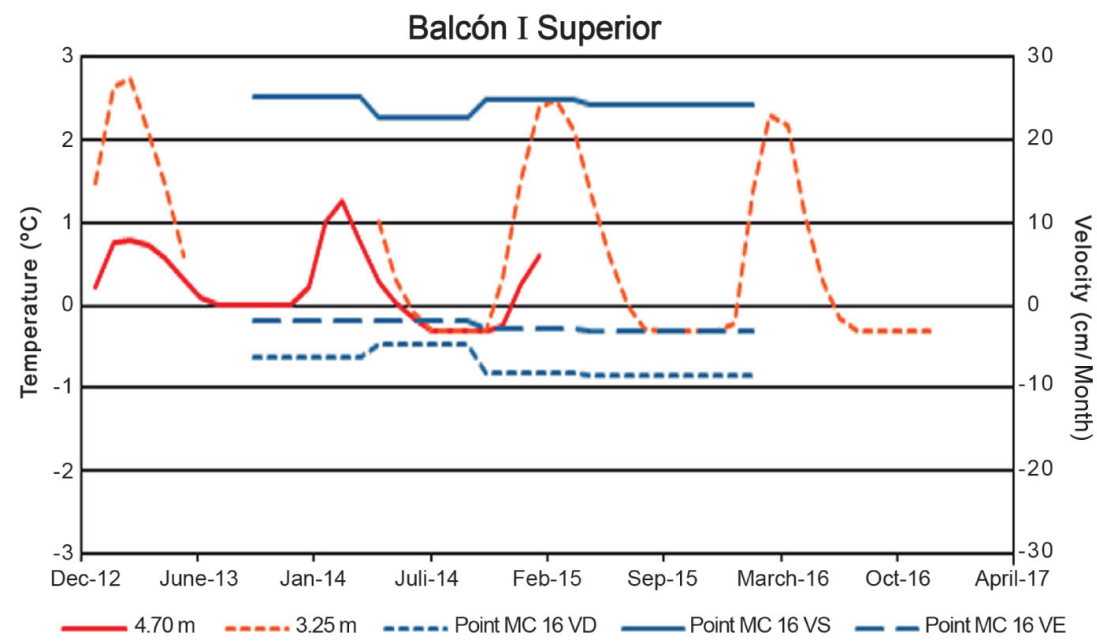

Figure 10. Annual horizontal surface velocities (blue) versus annual temperatures (red) at Balcón I Superior. 


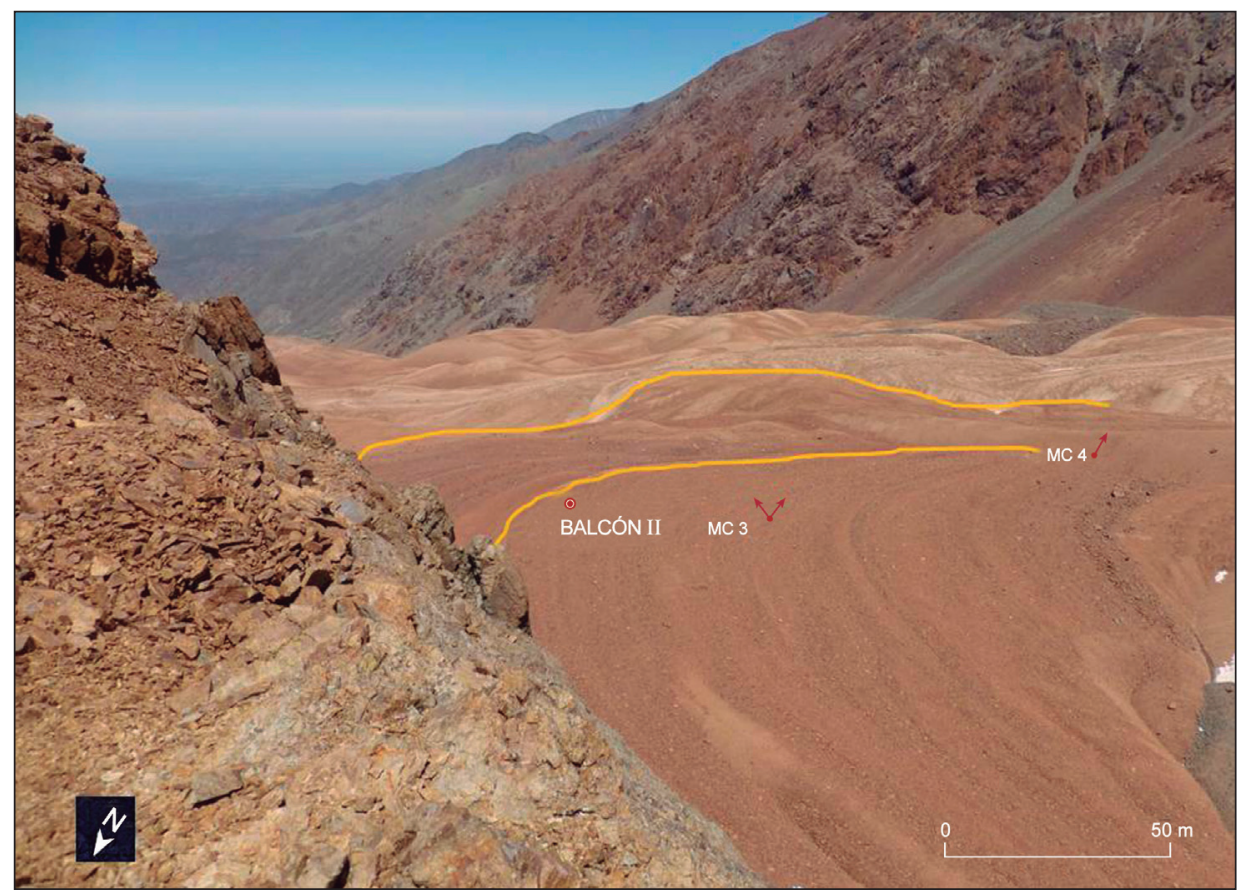

Figure 11. GPS points for kinematics at Balcón II. Distance between MC3 and MC4 =86m. The velocity vectors are not made in scale, they are exaggerated to indicate the orientation.

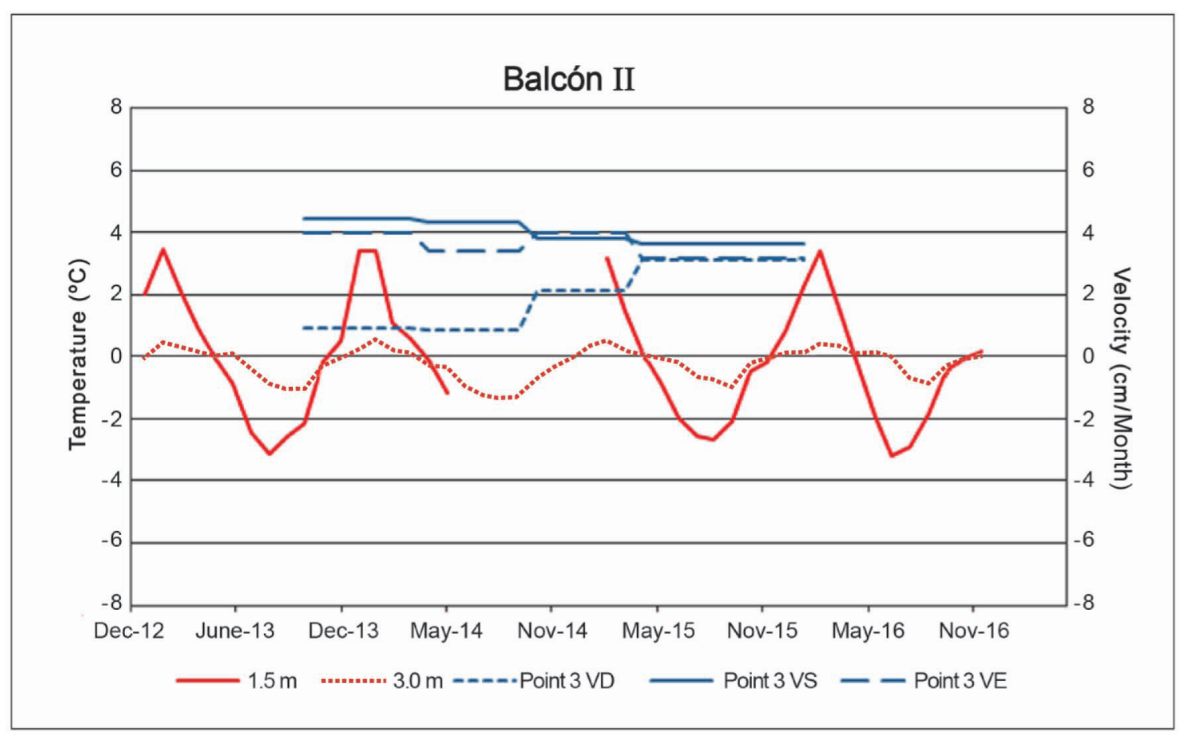

Figure 12. Annual horizontal surface velocities (blue) versus annual temperatures (red) at Balcón II. 
rock glacier advance faster. The follow up of the monitoring process at this rock glacier indicates- as shown in this contribution- that the melting of ice and the permafrost degradation produce a major internal circulation of water. However, periods with increased precipitation (as snowfall or rain depending on height) as during Niño phenomena for example, also correspond to major speed of the rock glacier lobes at Morenas Coloradas.

Kääb et al. (2007) indicated that rock glaciers are sensitive to current or recent climate changes (climatic variability) and that a large number of them in the Alps showed an increase in speed in recent years. They use a one-dimensional thermo-mechanically coupled numerical model and denoted the influence of water in the frozen material, which might be the most important factor for permafrost close to $0^{\circ} \mathrm{C}$, although it is difficult to model.

\section{Conclusions}

Active layers of three respective monitoring sites of the Morenas Coloradas rock glacier, Central Andes of Mendoza, Argentina for the period 2008-2016 are analyzed. A long-term kinematic accurate calculation ( $48 \mathrm{hs}$ ) of the rock glacier creep in the Andes is also presented for the first time.

The curves of the monitoring site Balcón I intersected the isotherm of $0^{\circ} \mathrm{C}$ between 7.5 and $8.3 \mathrm{~m}$ depth. These deep active layer boundaries with such considerable thickness should no longer be considered as transient layer, but as the transformation of the site into a thermal talik. Aggradation or degradation signs atop the permafrost at the snout of the rock glacier seem to be related not only to the regional temperature rise due to climatic variability in the studied period from 2008 until today, but also to subterranean melting water discharge during summer, rain percolation in the active layer and freezing phenomena in the sporadic humid layer above the top of the permafrost in the late summer. In this sense, the thickening of the active layer at Balcón I occurred because of years with increased precipitation such as Niño years.

Balcón I Superior shows clear indicators of warming, with a thickening of the active layer of approximately $10 \mathrm{~cm}$ per year and positive temperatures in the frozen horizon when the borehole was drilled in 2008. The role of rain percolation is not ruled out at this site. The active thickness layer at Balcón I Superior increased from $5 \mathrm{~m}$ to $6 \mathrm{~m}$ during the studied period.

The kinematic measurement points delimited perfectly well active from inactive zones of the rock glacier. All points moved southeast. Near Balcón I and Balcón I Superior this displacement was observed best. The movements surpassed $2 \mathrm{~m} /$ year at points MC18 and MC19 between Nov 2014 and 2015 as well as between May 2015 and Feb 2016. The movement of the cryogenic lobe where Balcón I Superior and MC 16 are located calls for special attention. The observed increase of the displacement rate is also validated with observed processes such as mass wasting at the front of the rock glacier and its advance in 2015/2016 over the totalizer located at the foot of the lobe. The negative topography in the sedimentary accumulation at the nose of the rock glacier is important because it is indicating a loss of volume, and possibly ice, from the rock glacier at lower altitudes. 
Balcón II only reveals a temperature rise during the warmest months intersecting the $0^{\circ} \mathrm{C}$ isotherm at increasing depths between February and March. At this altitude there is no rain percolation. The influence of melting water transport in its active layer however cannot totally be ruled out. In contrast to Balcón I superior, the points close to Balcón II, above 3700 m a.s.l., showed less movement indicating only 20-30 cm toward the $\mathrm{S}$ during the considered periods.

The measured warming affecting the active layer leads us to infer that the active layer and the internal structure of the rock glacier, especially at its snout, might be affected by external temperature. Changes in the internal structure were enhanced by secondary processes such as rainfall or melt water from the upper valley infiltrating the rock glacier. The highest site, Balcón I, however, maintained a negative caloric balance for longer time at the depth where the permafrost table was found in 2001, when the shallow borehole was made. The new situation observed since 2012, with a scenario of warmer summers, should be evaluated in the years to come.

The loss of different ice types and the degradation of ice-rich permafrost in the Morenas Coloradas rock glacier will affect the water balance and the hydrological contribution in the basin of the Vallecitos River and indirectly the human activities.

\section{Acknowledgments}

This work was made possible by the project: PIP-CONICET, 20110100507, "Identification of cryoforms and cryodynamics in the Central and Southern Andes and their relation to extraterrestrial environments". We thank the Geomatics Research Group and Meteorological Research Group of the Argentine Institute for Snow Research, Glaciology and Environmental Sciences, National Research Council (CONICET), Mendoza. We thank Pepe Hernández and Juan Pablo Scarpa for the fieldwork. We are especially grateful to Ivanna P. Marcosig for her unconditional assistance in the elaboration of the maps as well as to Daniel Dueñas for the improvement of the figures at the final step of the paper and special thanks to Sabine Herfert for the improvement of the English manuscript. We thank the international Group Climate and Cryosphere (CLIC) for the cooperation and support.

\section{References}

Ahumada, A.L., Ibáñez Palacios, G.P., Carilla, J., Toledo, M.A., Páez, S.V. 2015. Observaciones geomorfológicas en glaciares de escombros de los Andes tropicales de Argentina. Acta Lilloana 27, 2, 63-76. https://doi.org/10.30550/j.agl.

Barsch, D. 1977. Alpiner permafrost: ein Beitrag zur Verbreitung, zum Charakter und zur Ökologie am Beispiel der Schweizer Alpen. In: H. Poser (Ed.), Formen, Formengesellschaften und Untergrenzen in den heutigen periglazialen Höhenstufen der Hochgebirge Europas und Afrikas zwischen Arktis and Äquator. Abhandlungen des Akademie Wissenchaften in Göttingen. Mathematisch-Physikalische Klasse Folge 3, 118-141. https://doi.org/10.3112/ erdkunde.1976.04.07.

Barsch, D. 1996. Rockglaciers. Springer, Berlin, 331 pp. https://doi.org/10.1007/978-3642-80093-1. Barsch, D., King, L. 1989. Origin and geoelectrical resistivity of rockglaciers in semi-arid subtropical mountains (Andes de Mendoza, Argentina). Zeitschrift für Geomorphologie 33 (2), 151-163. 
Bennett, R.A., Hreinsdóttir, S., Velasco, M.S., Fay, N.P. 2007. GPS constraints on vertical crustal motion in the northern Basin and Range, Geophyical. Research Letters 34, L22319. https:// doi.org/10.1029/2007GL031515.

Blewitt, G., Lavallée, D. 2002. Effect of annual signals on geodetic velocity. Journal of Geophysical Research: Solid Earth 107 (B7). https://doi.org/10.1029/2001JB000570.

Bodin, X., Malet, E., Vernier, F., Marsy, G., Hadri, H., Trombotto, D. 2017. L'apport d'appareils photo reflex autonomes pour le suivi quasi-continu de la dynamique des glaciers rocheux. exemples dans les Alpes et dans les Andes. Université de Savoie and CNRS, Monitoring en Milieux Naturels, Collection EDYTEM 19, 47-53.

Bodin, X., Trombotto, D. 2015. Evaluation of a terrestrial photogrammetry method for the study of high mountain dynamics: Quebrada del Medio rock glacier, Mendoza, Argentina. In: J. Jasiewicz, Z. Zwoliński, H. Mitasova, T. Hengl (Eds), Geomorphometry for Geosciences. Adam Mickiewicz University in Poznań, pp. 189-291.

Buk, E. 1983. Glaciares de escombros y su significación hidrológica. Acta Geocriogénica 1, 22-38.

Burn, C.R., Smith, C.A.S. 1988. Observations of the "thermal offset" in near-surface mean annual ground temperatures at several sites near Mayo, Yukon Territory, Canada. Arctic 41 (2), 99104. https://doi.org/10.14430/arctic1700.

Caminos, R., 1979. Cordillera Frontal. Segundo Simposio de Geología Regional Argentina, Córdoba, pp. 397-453.

Catalano, L. 1926. Contribución al conocimiento de los fenómenos geofísicos atmosféricos. Buenos Aires: Dirección General de Minas, Geología e Hidrología, Publicación 24, 78 pp.

Corte, A.E. 1976a. Rock Glaciers. Biuletyn Peryglacjalny 26, 175-197.

Corte, A.E. 1976b. The hydrological significance of rock glaciers. Journal of Glaciology 17, 157158. https://doi.org/10.1017/S0022143000030859.

Corte, A. 1997. Geocriología. El Frío en la Tierra. Ediciones Culturales de Mendoza, Fundar Editorial Gráfica, 398 pp.

Corte, A., Trombotto, D. 1984. Quartz grain surface textures in laboratory experiments and in field conditions of rock glaciers. Microscopía Electrónica y Biología Celular 8 (1), 71-79.

Delaloye, R., Perrouchoud, E., Avian, M., Kaufmann, V., Bodin, X., Hausmann, H., Ikeda, I., Kääb, A., Kellerer-Pirklbauer, A., Krainer, K., Lambiel, Ch., Mihajlovic, D., Staub, B., Roer, I., Thibert, E. 2008. Recent interannual variations of rock glacier creep in the European Alps. Proceedings of the $9^{\text {th }}$ International Conference on Permafrost, Fairbanks, USA, pp. 343-348.

Giardino, J.R., Shroeder, Jr., Vitek, J. 1987. Rock Glaciers. Allen \& Unwin, Winchester, 355 pp.

Delaloye, R., Lambiel, C., Roer, I. 2010. Overview of rock glacier kinematics research in the Swiss Alps. Seasonal rhythm, interannual variations and trends over several decades. Geographica Helvetica 65: 135-145. https://doi.org/10.5167/uzh-38562.

Götz, J., Keuschnig, M., Hartmeyer, I., Trombotto, D., Schrott, L. 2008. Geophysical prospection on a complex rock glacier system - Morenas Coloradas, revisited (Cordón del Plata, Mendoza, Argentina. In: L. Schrott, J. Otto (Eds.), 3 Mitteleuropäischen Geomorphologietagung. Tagungsband, Salzburg, p. 80.

Haeberli, W. 1985. Creep of Mountain Permafrost. Mitteilungen der Versuchsanstalt für Wasserbau, Hydrologie und Glaziologie 77, 142 pp.

Haeberli, W., Huder, J., Keusen, H.R., Pika, J., Röthlisberger, H. 1988. Core drilling through rock glacier-permafrost. Vth-International Conference on Permafrost, Trondheim, Proceedings, V 1, Norway, pp. 937-941.

Halla, Ch., Blöthe, J., Trombotto Liaudat, D., Schrott, L. 2018. Permafrost in den argentinischen Anden - ein bedeutender Wasserspeicher. Geographische Rundschau 11, 36-40. 
Hernández, J. 2002. Perforadora a percusión para suelos detríticos criogénicos. In: D. Trombotto, R. Villalba (Eds.), IANIGLA, 1973-2003: 30 años de Investigación Básica y Aplicada en Ciencias Ambientales, Editorial ZETA, Mendoza, pp. 71-72.

Ikeda, A., Matsuoka, N., Kääb, A. 2008. Fast deformation of perennially frozen debris in a warm rock-glacier in the Swiss Alps: an effect of liquid water. Journal of Geophysical Research 113, F01021. https://doi.org/10.1029/2007JF000859.

International Permafrost Association (IPA) 1998. Multilanguage Glossary of Permafrost and Related Ground-Ice Terms R.O. Van Everdingen (Ed.). The Arctic Institute of North America, The University of Calgary, Alberta.

Jones, P.D., Moberg, A. 2003. Hemispheric and large-scale surface air temperature variations: an extensive revision and an update to 2001. Journal of Climate 16, 206-223. https://doi. org/10.1175/152-0442(2003)016<02016:HALSSA>2.0.CO;2.

Kääb, A., Frauenfelder, R., Roer, I. 2007. On the response of rock glacier creep to surrface temperature increse. Global and Planetary Change 56, 172-187. https://doi.org/10.1016/j. gloplacha.2006.07.005.

Lambiel, C. 2011. Le glacier rocheux déstabilisé de Tsaté-Moiry: caractéristiques morphologiques et vítese de déplacement. In: C. Lambiel, E. Reynard, C Scapozza, C. (Eds), La géomorphologie alpine: entre patrimoine et contrainte. Actes du colloque de la Société Suisse de Géomorphologie. Géovisions 36, 211-224. http://www.unil.ch/igul/page84172. html [23 May 2013].

Lambiel, C., Delaloye, R. 2004. Contribution of real time kinematic GPS in the study of creeping mountain permafrost: examples from the Western Swiss Alps. Permafrost and periglacial Processes 15 (3), 229-241. https://doi.org/10.1002/ppp.496.

Little, J.D., Sandall, H., Walegur, M.T., Nelson, F.E. 2003. Application of differential global positioning systems to monitor frost heave and thaw settlement in tundra environments. Permafrost and Periglacial Processes 14 (4), 349-357. https://doi.org/10.1002/ppp.466.

Lliboutry, L., Corte, A.E. 1998. Glaciers of South America-Glaciers of Chile and Argentina. In: R. Williams, J. Ferrigno (Eds.), Satellite Image Atlas of Glaciers of the World: South America. United States Geological Survey, Washington, pp. 109-206. https://doi.org/10.3133/pp1386J.

Martini, M.A., Strelin, J.A., Astini, R.A. 2014. Monitoreo térmico y medición del flujo superficial del glaciar de escombros Varas, Sierra de Zenta, Cordillera Oriental (noroeste argentino). In: Actas XIX Congreso Geológico Argentino, Córdoba, Argentina.

Noetzli, J., Vonder Mühl, D. (Eds.). 2010. Permafrost in Switzerland. Glaciologial report (Permafrost) Nr.8/9, University of Zürich, SCNAT, 68 pp.

Rosenblüth, B., Fuenzalida, H.A., Aceituno, P. 1997. Recent temperature variations in southern South America. International Journal of Climatology 17, 67-85. https://doi.org/10.1002/ (SICI) 1097-0088(199701)17:1<67::AID-JOC120>3.0.CO;2-G.

Scapozza, C., Lambiel, Ch., Bozzini, C., Mari, S., Conedera, M. 2014. Assessing the rock glacier kinematics on three different timescales: a case study from the southern Swiss Alps. Earth Surface Processes and Landforms 39, 2056-2069. https://doi.org/10.1002/esp.3599.

Smith, S., Brown, J. 2009. Permafrost and seasonally frozen ground. Global Terrestrial Observing System, Rome, GTOS Secretariat, NRL, FAO, 22 pp.

Trombotto, D. 1985. Análisis preliminar de estructuras geocriogénicas mediante texturas de grano de cuarzo con la aplicación del microscopio electrónico. Revista de la Asociación Geológica Argentina 11 (3-4), 184-201.

Trombotto, D. 1991. Untersuchungen zum periglazialen Formenschatz und zu periglazialen Sedimenten in der "Lagunita del Plata", Mendoza, Argentinien. Heidelberger Geographische Arbeiten 90, 171 pp. 
Trombotto, D. 2003. Mapping of permafrost and the periglacial environment, Cordón del Plata, Argentina. In: W. Haeberli, D. Brandová (Eds.), $8^{\text {th }}$ International Conference on Permafrost. Extended Abstracts, Reporting Current Research and New Information, Zürich, pp. 161-162.

Trombotto, D., Buk, E., Hernández, J. 1997. Monitoring of Mountain Permafrost in the Central Andes, Argentina. Permafrost and Periglacial Processes 8, 123-129. https://doi. org/10.1002(SICI)1099-1530(199701)8:1<123::AID-PPP242>3.3.CO;2-D.

Trombotto, D., Buk, E., Hernández, J. 1999. Rock glaciers in the Southern Central Andes (appr. $33^{\circ}$ S.L.), Mendoza, Argentina: a review. Bamberger Geographische Schriften 19, 145-173.

Trombotto, D., Ahumada, A.L. 2005. Los Fenómenos Periglaciales. Identificación, Determinación y Aplicación. Opera Lilloana 45 Fundación "Miguel Lillo", San Miguel de Tucumán, 131 pp.

Trombotto Liaudat, D., Blöthe, J.H., Keuschnig, M., Hernández, J., Götz, J., Hartmeyer, I., Schrott, L. 2008. Detection of permafrost aggradation at Balcón I, Morenas Coloradas Rockglacier, Mendoza, Argentina. In: L. Schrott, J. Otto (Eds.), 3 Mitteleuropäischen Geomorphologietagung. Salzburg, p. 81.

Trombotto, D., Borzotta, E. 2009. Indicators of present global warming through changes in active layer-thickness, estimation of thermal difussivity and geomorphological observations in the Morenas Coloradas rock glacier, Central Andes of Mendoza, Dry Andes, Argentina. Cold Regions Science and Technology 55, 321-330. https://doi.org/10.1016/j. coldregions.2008.08.009.

Trombotto Liaudat, D., Wainstein, P., Arenson, L.U. 2014. Terminological guide of the South American geocryology. Vázquez Mazzini Editores, Buenos Aires, 127 pp.

Trombotto Liaudat, D., Sileo, N., Dapeña, C. Submitted. Advances in the periglacial hydrology of the Stepanek rock glacier, Andes Centrales, Mendoza, Argentina. Permafrost and Periglacial Processes. Submitted.

United Nations Environment Programme (UNEP). 2007. Global Outlook for Ice and Snow. Birkenland Trykkeri A/S, Birkenland, Norway.

Van Everdingen, Robert O. (Eds.). 1998. Multilanguage Glossary of Permafrost and Related Ground-Ice Terms. International Permafrost Association, The Arctic Institute of North America, The University of Calgary, Alberta, $207 \mathrm{pp}$.

Wahrhaftig, C., Cox, A. 1959. Rock glaciers in the Alaska Range. Bulletin of the Geological Society of America 70, 383-436. https://doi.org/10.1130/0016-7606(1959)70[383:RGITAR ]2.0.CO;2. 
